\title{
PENERAPAN REGRESI LOGISTIK BINER MULTILEVEL DALAM ANALISIS PENGARUH KARAKTERISTIK INDIVIDU, RUMAH TANGGA, DAN WILAYAH TERHADAP STATUS KEMISKINAN BALITA DI KEPULAUAN MALUKU DAN PULAU PAPUA \\ Analisis Hasil Survei Sosial Ekonomi Nasional 2019
}

\author{
(Aplication of Multilevel Binary Logistic Regression in the Analysis of the Effect of \\ Individual, Household, and Area Characteristics on Poverty of Children Under Five Years in \\ Maluku and Papua Islands)
}

\section{Ovilia Vebi Amida1, Jeffry Raja Hamonangan Sitorus²}

Politeknik Statistika STIS ${ }^{1}$

Politeknik Statistika STIS ${ }^{2}$

Jalan Otto Iskandardinata No.64C, Bidara Cina, Kecamatan Jatinegara, Kota Jakarta Timur, Daerah Khusus Ibukota Jakarta 13330

E-mail: oviamida@gmail.com

\begin{abstract}
ABSTRAK
Kemiskinan merupakan masalah sosial ekonomi yang dihadapi setiap negara terutama negara berkembang seperti Indonesia. Kelompok umur dengan persentase kemiskinan tinggi adalah kelompok umur bayi (kurang dari 1 tahun) dan balita (0 sampai 4 tahun). Menurut ahli dalam ilmu psikologi, Duncan dan Magnuson (2011), kemiskinan di awal kehidupan anak sangat berbahaya karena perkembangan otak dan struktur saraf anak umur dini membentuk hasil kognitif, sosial, emosional, dan kesehatan di masa depan. Berdasarkan sebaran anak miskin menurut pulau, angka kemiskinan, kedalaman kemiskinan, dan keparahan kemiskinan anak tertinggi berada di Kepulauan Maluku dan Pulau Papua (BPS, 2017). Berdasarkan Teori Ekologis Bronfenbrenner (1979) dan kerangka pikir teoritis determinan kemiskinan UNICEF oleh Gaspar Fajth, kemiskinan anak dipengaruhi oleh karakteristik individu, rumah tangga, dan wilayah. Sehingga, penelitian ini bertujuan untuk mengetahui gambaran serta pengaruh karekteristik individu, rumah tangga, dan wilayah terhadap status kemiskinan anak kurang dari 5 tahun di Kepulauan Maluku dan Pulau Papua. Dengan demikian, metode analisis yang digunakan dalam penelitian ini adalah regresi logistik biner multilevel dengan 3 level. Penelitian ini menggunakan data Survei Sosial Ekonomi Nasional 2019 dan beberapa data publikasi BPS. Unit analisis dalam penelitian ini adalah balita (anak kurang dari 5 tahun). Status kemiskinan balita ditentukan menggunakan pendekatan multidimensi yaitu Multiple Overlapping Deprivation Analysis (MODA). Hasil analisis menunjukkan bahwa status kemiskinan balita di Kepulauan Maluku dan Pulau Papua dipengaruhi oleh karakteristik individu (umur balita), rumah tangga (pendidikan dan umur kepala rumah tangga, pendidikan dan status bekerja ibu, status kemiskinan dan jumlah anggota rumah tangga, serta tipe daerah), dan wilayah (IPM).
\end{abstract}

Kata kunci: kemiskinan balita, regresi logistik biner, analisis multilevel

\section{ABSTRACT}

Poverty is a socio-economic problem in every country, especially developing countries like Indonesia. Age groups with a high percentage of poverty are infants (less than 1 year) and toddlers ( 0 to 4 years). According to experts in psychology, Duncan and Magnuson (2011), poverty early in a child's life is very dangerous because the development of the brain and nervous structures of early childhood shapes cognitive, social, emotional, and health outcomes in the future. Based on the distribution of poor children by island, the highest poverty rates, poverty depths, and severity of child poverty are in the Maluku Islands and Papua Island (BPS, 2017). Based on Bronfenbrenner's Ecological Theory (1979) and the UNICEF determinant theoretical framework of poverty by Gaspar Fajth, child poverty is influenced by individual, household, and 
regional characteristics. Thus, this study aims to determine the description and influence of individual, household, and regional characteristics on the poverty status of children less than 5 years age in the Maluku Islands and Papua Island. Thus, the method of analysis used in this study is multilevel binary logistic regression with 3 levels. This research uses the National Socio-Economic Survey 2019 and some BPS publication data. The unit of analysis in this study was children less than 5 years. The poverty status of children under five is determined using a multidimensional approach, namely Multiple Overlapping Deprivation Analysis (MODA). The results of the analysis show that the poverty status of children under five in Maluku Islands and Papua Island is influenced by individual characteristics (age), household (education and age of the head of the household, mother's education and work status, poverty status and number of household members, and type of area), and region (IPM).

Keywords: child poverty, binary logistic regression, multilevel analysis 


\section{PENDAHULUAN}

Kemiskinan merupakan masalah sosial ekonomi yang dihadapi setiap negara terutama negara berkembang seperti Indonesia. Banyaknya pengaruh dan permasalahan yang disebabkan oleh kemiskinan menempatkan penanganan kemiskinan sebagai tujuan utama pembangunan, baik pembangunan global maupun nasional. Tujuan Pembangunan Millenium (Millenium Development Goals disingkat MDGs) yang pertama adalah memberantas kemiskinan dan kelaparan ekstrem. MDGs telah resmi berakhir pada tahun 2015. Mengingat berbagai dampak dan permasalahan yang ditimbulkan, kemiskinan kembali menjadi salah satu Tujuan Pembangunan Berkelanjutan (Sustainable Development Goals disingkat SDGs). Tujuan SDGs terkait dengan kemiskinan adalah mengakhiri kemiskinan dalam segala bentuk dimanapun. Pemerintah Indonesia juga berkomitmen untuk menekan angka kemiskinan. Pengentasan kemiskinan menjadi salah satu sasaran utama dalam Rencana Pembangunan Jangka Panjang Nasional (RPJPN) 2005-2025. Sebagai tindak lanjut RPJPN 2005-2025, Rencana Pembangunan Jangka Menengah Nasional (RPJMN) IV 2020-2024 menargetkan tingkat kemiskinan menurun menjadi 6,5 sampai 7 persen pada tahun 2024 . Persentase penduduk miskin di Indonesia tahun 2012 sampai 2019 secara umum menurun. Akan tetapi, penurunan persentase penduduk miskin relatif kecil bahkan pada September 2013 dan Maret 2015 terjadi peningkatan. Jumlah penduduk miskin di Indonesia dari tahun ke tahun masih tergolong besar. Pada tahun 2019, jumlah penduduk miskin di Indonesia sebesar 25,14 juta orang. Beberapa hasil penelitian menunjukkan bahwa penurunan kemiskinan di Indonesia tidak signifikan. Sutikno (2010) membuktikan bahwa progam-program pengentasan kemiskinan yang dilaksanakan belum secara signifikan menurunkan jumlah penduduk miskin. Selanjutnya, menurut Harianto (2018), berbagai upaya penanggulangan kemiskinan yang telah lama dilakukan oleh pemerintah tidak berdampak secara signifikan pada penurunan angka kemiskinan.

Pada tahun 2015 sampai 2018, persentase penduduk miskin berumur kurang dari 18 tahun selalu lebih besar dari pada penduduk berumur 18 tahun atau lebih. Hal tersebut menunjukkan bahwa kemiskinan bukan hanya dialami penduduk dewasa melainkan juga anak-anak termasuk bayi dan balita. Menurut publikasi BPS (2017), kelompok umur dengan persentase kemiskinan tinggi adalah kelompok umur bayi (kurang dari 1 tahun) dan balita ( 0 sampai 4 tahun). Menurut ahli dalam ilmu psikologi, Duncan dan Magnuson (2011), kemiskinan di awal kehidupan anak sangat berbahaya karena perkembangan otak dan struktur saraf anak umur dini membentuk hasil kognitif, sosial, emosional, dan kesehatan di masa depan. Berdasarkan sebaran anak miskin menurut pulau, angka kemiskinan, kedalaman kemiskinan, dan keparahan kemiskinan anak tertinggi berada di Kepulauan Maluku dan Pulau Papua (BPS, 2017). Untuk menurunkan angka kemiskinan anak di Kepulauan Maluku dan Pulau Papua, diperlukan suatu kebijakan yang akurat dan tepat sasaran. Kebijakan yang akurat dan tepat sasaran dapat diterapkan secara efektif dan efisien apabila telah diketahui karakteristik dari anak-anak yang mengalami kemiskinan. Berdasarkan Teori Ekologis Bronfenbrenner (1979) dan kerangka pikir teoritis determinan kemiskinan UNICEF oleh Gaspar Fajth, kemiskinan anak dipengaruhi oleh karakteristik individu, rumah tangga, dan wilayah. Sehingga, penelitian ini bertujuan untuk mengetahui gambaran serta pengaruh karekteristik individu, rumah tangga, dan wilayah terhadap status kemiskinan anak kurang dari 5 tahun di Kepulauan Maluku dan Pulau Papua. Karakteristik individu, rumah tangga, dan wilayah yang memengaruhi status kemiskinan balita ditentukan melalui permodelan statistik menggunakan metode regresi logistik biner multilevel dengan 3 level yaitu individu sebagai level 1 , rumah tangga sebagai level 2, dan wilayah kabupaten/kota sebagai level 3.

\section{METODE}

\section{Kemiskinan Anak}

Menurut beberapa ahli, konsep kemiskinan anak tidak sesederhana konsep kemiskinan pada umumnya. Feeny dan Boyden (2003) menyatakan bahwa konsep kemiskinan anak meliputi deprivation (perampasan), exclusion (pengucilan), dan vulnerability (kerentanan). UNICEF (2005) 
mendefinisikan kemiskinan anak sebagai kondisi perampasan sumber daya baik materi, spiritual, maupun emosional yang dibutuhkan untuk bertahan hidup, berkembang, dan berpartisipasi dalam masyarakat.

\section{Pengukuran Kemiskinan Anak}

Beberapa lembaga penelitian internasional telah mengembangkan pengukuran kemiskinan anak menggunakan pendekatan multidimensi. Pada tahun 2003, Universitas Bristol Inggris mengembangkan penelitian kemiskinan multidimensi anak dan hasil penelitiannya dikenal dengan Metode Bristol. Metode Bristol terdiri dari 8 dimensi yaitu makanan, air minum, sanitasi, kesehatan, perumahan, pendidikan, informasi, dan akses layanan. Pendekatan kedua adalah Multidimensional Poverty Index (MPI) yang dikembangkan oleh Oxford Poverty and Human Development Initiative (OPHI). Unit analisis metode MPI adalah rumah tangga. Sehingga, status kemiskinan anak ditentukan berdasarkan status kemiskinan rumah tangga dimana anak tinggal. MPI terdiri dari 3 dimensi yaitu pendidikan, kesehatan, dan kualitas standar hidup. United Nations Children's) mengembangkan pengukuran kemiskinan anak menggunakan pendekatan multidimensi yang dikenal dengan Multiple Overlapping Deprivation Analyisis (MODA).

\section{Faktor-Faktor yang Memengaruhi Kemiskinan Anak}

Berdasarkan Teori Ekologis Bronfenbrenner, terdapat 4 kategori karakteristik yang memengaruhi kehidupan individu yaitu microsystem, mesosystem, exosystem, dan macrosystem (Bronfrenbenner, 1979). Microsystem yang terdiri dari keluarga, fasilitas kesehatan, sekolah, teman sebaya, area bermain, kelompok beribadah serta karakteristik individu seperti jenis kelamin, kesehatan, dan umur memberikan pengaruh utama dan langsung pada kehidupan. Hasil penelitian UNICEF (2007) oleh Gaspar Fajth menunjukkan bahwa latar belakang yang memengaruhi kemiskinan anak terdiri dari 3 dimensi yaitu dimensi individu, rumah tangga, dan geografis. Dimensi individu meliputi umur dan jenis kelamin. Dimensi rumah tangga terdiri dari ukuran rum ah tangga, pendidikan kepala rumah tangga, jenis kelamin kepala rumah tangga, indeks kemakmuran, etnis/bahasa/agama, pekerjaan, kesakitan/disabilitas kepala rumah tangga, kerentanan rumah tangga, dan akses jaminan sosial. Dimensi geografis dapat berupa wilayah kabupaten/kota, provinsi, atau negara.

Berdasarkan Teori Ekologis Bronfenbrenner dan kerangka pikir teoritis hasil penelitian UNICEF oleh Gaspar Fajth, kemiskinan balita dipengaruhi oleh karakteristik individu, rumah tangga, dan wilayah. Karakteristik individu, rumah tangga, dan wilayah yang diduga memengaruhi kemiskinan balita, antara lain:

1. Umur Balita

Beberapa penelitian menunjukkan bahwa umur balita memengaruhi status kemiskinan. Penelitian Adetola dan Olufemi (2012) dan Prasetyo (2010) menunjukkan bahwa semakin bertambah umur balita, peluang balita untuk menjadi miskin semakin kecil.

2. Jenis Kelamin Balita

Anak perempuan memiliki persentase kemiskinan anak lebih besar dari pada anak laki-laki (Prasetyo, 2010). Hal tersebut terkait kesenjangan gender antara anak laki-laki dan perempuan. Nilai ekonomi atau tingkat pengembalian anak laki-laki dianggap lebih tinggi dari pada anak perempuan (Karisma, 2017). Dengan demikian anak perempuan memiliki risiko lebih tinggi untuk mengalami kemiskinan dibandingkan dengan anak laki-laki.

3. Pendidikan Kepala Rumah Tangga

Beberapa penelitian terdahulu menunjukkan bahwa pendidikan kepala rumah tangga mempengaruhi kemiskinan balita. Pusponegoro (2013) dan Bachtiar (2016) menyatakan bahwa pendidikan kepala rumah tangga signifikan memengaruhi kemiskinan balita.

4. Pendidikan Ibu

Ibu memiliki peran penting dalam pemenuhan kebutuhan dasar balita. Pusponegoro (2013) dan Bachtiar (2016) menyatakan bahwa pendidikan ibu signifikan mempengaruhi kemiskinan anak.

5. Status Bekerja Kepala Rumah Tangga 
Kepala rumah tangga identik dengan tulang punggung keluarga, pencari nafkah, atau orang yang bertanggung jawab memenuhi kebutuhan dalam suatu rumah tangga. Status bekerja kepala rumah tangga berhubungan dengan pendapatan dan pemenuhan kebutuhan rumah tangga. Kepala rumah tangga yang bekerja memperoleh pendapat yang dapat digunakan untuk memenuhi kebutuhan rumah tangganya. Bastos dan Machado (2009) menyatakan bahwa status bekerja kepala rumah tangga menentukan status kemiskinan anak. Anak yang tinggal bersama kepala rumah tangga menganggur memiliki risiko yang lebih besar untuk miskin.

6. Status Bekerja Ibu

Beberapa penelitian terdahulu menunjukkan bahwa status bekerja ibu memengaruhi kemiskinan balita. Pusponegoro (2013) menyatakan bahwa status bekerja ibu signifikan memengaruhi kemiskinan anak umur kurang dari 5 tahun. Anak yang ibunya bekerja memiliki kecenderungan yang lebih tinggi untuk menjadi dari pada anak yang ibunya tidak bekerja.

7. Umur Kepala Rumah Tangga

Salah satu fakor yang memengaruhi kemiskinan balita adalah umur kepala rumah tangga. Adetola dan Olufemi (2013) menyatakan bahwa umur kepala rumah tangga signifikan memengaruhi kemiskinan anak balita.

8. Jumlah Anggota Rumah Tangga

Sesuai dengan anjuran Badan Kependudukan dan Keluarga Berencana (BKKBN) untuk memiliki paling banyak 2 anak, maka jumlah anggota rumah tangga dalam suatu keluarga diharapkan tidak lebih dari 4. Semakin banyak jumlah anggota rumah tangga maka semakin besar tanggungan dalam rumah tangga tersebut. (Ramadhani, 2017) menyatakan bahwa jumlah anggota rumah tangga signifikan memengaruhi status kemiskinan anak. Selanjutnya, penelitian Adetola dan Olufemi (2012) menunjukkan bahwa jumlah anggota rumah tangga yang banyak meningkatkan peluang balita untuk miskin multidimensi.

9. Kemiskinan Rumah Tangga

Beberapa penelitian kemiskinan menunjukkan bahwa kemiskinan rumah tangga memengaruhi kemiskinan anak. Penelitian Bachtiar (2016) menunjukkan bahwa status kemiskinan rumah tangga memengaruhi kemiskinan balita. Balita yang tinggal di rumah tangga tidak miskin memiliki peluang yang lebih tinggi untuk tidak miskin dari pada anak yang tinggal di rumah tangga miskin.

10. Tipe Daerah

Seringkali terdapat kesenjangan sosial antara daerah pedesaan dan perkotaan. Salah satu bentuk kesenjangan sosial yang terjadi adalah kemiskinan anak. Berbagai penelitian membuktikan bahwa tipe daerah berhubungan dengan kemiskinan anak. Penelitian kemiskinan balita oleh Pusponegoro (2010) membuktikan bahwa kemiskinan anak balita dipengaruhi oleh wilayah tempat tinggal. Kemudian, Prasetyo (2010) dan Bachtiar (2016) menyatakan bahwa anak yang tinggal di pedesaan memiliki peluang lebih besar untuk menjadi miskin dari pada anak-anak yang tinggal di daerah perkotaan.

11. Indeks Pembangunan Manusia

Salah satu manfaat IPM adalah mengukur keberhasilan dalam upaya membangun kualitas hidup manusia. IPM menggambarkan keberhasilan penduduk dalam mengakses hasil pembangunan dalam memperoleh pendapatan, pendidikan, kesehatan, dan sebagainya. Semakin tinggi nilai IPM maka pembangunan kualitas hidup manusia di suatu wilayah semakin baik.

\section{Multiple Overlapping Deprivation Analyisis (MODA)}

Pada peneltian ini, kemiskinan anak dihitung menggunakan pendekatan multidimensi MODA. MODA memberikan pendekatan komprehensif untuk mengukur kemiskinan dan deprivasi pada anak. MODA mengadopsi definisi kesejahteraan anak dan lebih menekankan pada pemenuhan terhadap kebutuhan barang dan jasa yang sangat penting untuk untuk pertumbuhan dan perkembangan. Karakteristik MODA yang membedakan dengan analisis lain yaitu menggunakan anak sebagai unit analisis, mengelompokan umur anak berdasarkan kebutuhan anak yang heterogen, mengukur kemiskinan dari berbagai dimensi dengan beberapa indikator dalam setiap dimensinya, serta membantu perancangan kebijakan yang efektif karena fokus pada anak yang terdeprivasi multidimensi dan sangat kekurangan (de Neubourg, 2012). 
Pemilihan dimensi dan indikator CC-MODA disesuaikan dengan kesejahteraan anak dalam Convention on the Rights of the Child (CRC). Kemudian, kerangka konsep MODA nasional (NMODA) dapat disesuaikan dengan norma, standar, dan konsep yang disepakati secara nasional terkait dengan hak-hak dasar anak. Pemilihan dimensi dan indikator MODA Indonesia didasarkan pada kajian literatur yang terdiri dari Undang-Undang Perlindungan Anak, ketersediaan data dan variabel SUSENAS yang sesuai dengan target RPJMN dan SDGs, serta analisis sensitifitas data (BPS, 2017).

\section{Regresi Logistik Biner}

Regresi logistik biner merupakan model regresi dengan variabel tak bebas kualitatif yang terdiri dari dua kategori (outcome biner). Model regresi logistik untuk outcome biner terdiri dari random component, systematic component, dan link function. Model regresi logistik dengan $\mathrm{p}$ variable penjelas adalah sebagai berikut:

$$
\operatorname{logit}(\pi)=\ln \left[\frac{\pi}{1-\pi}\right]=\beta_{0}+\beta_{1} x_{i 1}+\beta_{2} x_{i 2}+\cdots+\beta_{p} x_{i p}=\beta_{0}+\boldsymbol{\beta} \chi
$$

Dimana $\boldsymbol{\beta}$ merupakan vektor parameter koefisien regresi $\beta_{1}, \beta_{2}, \ldots, \beta_{p}$, dan $\chi$ merupakan vektor variabel bebas $\mathrm{X}_{1}, \mathrm{X}_{2}, \ldots, \mathrm{X}_{\mathrm{p}}$.

\section{Analisis Multilevel}

Analisis multilevel digunakan untuk megetahui pengaruh variabel prediktor yang tingkatannya berbeda. Model multilevel dikelompokkan menjadi 2 yaitu model multilevel dengan random intercept dan model multilevel dengan random slope. Pada model multilevel dengan random intercept, pengaruh setiap variabel prediktor terhadap variabel respon sama untuk masing-masing kelompok. Sedangkan, model multilevel dengan random slope memungkinkan pengaruh variabel prediktor terhadap variabel respon berbeda-beda untuk setiap kelompok. Model multilevel dengan $\mathrm{p}$ variabel penjelas adalah sebagai berikut:

$$
Y_{i j}=\beta_{0 j}+\beta_{1 j} X_{1 i j}+\cdots+\beta_{p j} X_{p i j}+e_{i j}
$$

$\beta_{\mathrm{oj}}$ merupakan intersep, $\beta_{1 \mathrm{j}}$ merupakan kemiringan untuk variabel $X_{1}, \beta_{\mathrm{pj}}$ merupakan kemiringan untuk variabel $X_{p}$, dan $e_{i j}$ merupakan residual error. Subskrip j menunjukkan kelas $1,2, \ldots$, J dan subskrip i untuk masing-masing individu $1,2, \ldots, \mathrm{n}_{\mathrm{j}}$ (Hox, 2018).

Langkah-langkah untuk mendapatkan model regresi multilevel terbaik adalah sebagai berikut (Hox, 2018):

1. Pemilihan struktur random intercept

2. Pemilihan struktur random slope

3. Pemilihan struktur fixed effect

4. Menyusun model terbaik dengan menambahkan intercept dan slope yang terpenuhi beserta interaksi interklas yang terpenuhi.

\section{Cakupan Penelitian}

Data yang digunakan adalah data Survei Sosial Ekonomi Nasional 2019 dan beberapa data publikasi BPS. Data Survei Sosial Ekonomi Nasional KOR serta Modul Konsumsi dan Pengeluaran digunakan untuk melihat indikator-indikator penentu status kemiskinan anak dengan pendekatan multidimensi serta mengetahui karakteristik individu dan rumah tangga. Kemudian, data mengenai karakteristik wilayah diperoleh dari publikasi masing-masing Provinsi yaitu publikasi Provinsi Maluku Dalam Angka 2020, Provinsi Maluku Utara Dalam Angka 2020, Provinsi Papua Dalam Angka 2020, dan Provinsi Papua Barat Dalam Angka 2020.

Data yang digunakan pada penelitian ini adalah data berstruktur hirarki 3 level yaitu level individu, rumah tangga, dan kabupaten/kota. Kemudian, unit analisis dalam penelitian ini adalah anak kurang dari 5 tahun. Penelitian ini mencakup 4 provinsi di Kawasan Timur Indonesia yaitu Provinsi Maluku, Provinsi Maluku Utara, Provinsi Papua, dan Provinsi Papua Barat. Masing-masing provinsi secara berurutan terdiri dari 11, 10, 29, dan 13 kabupaten/kota. Sehingga, penelitian ini 
mencakup 63 kabupaten/kota. Jumlah sampel yang tercakup dalam penelitian ini sebanyak 13.310 balita.

\section{Metode Analisis}

Analisis deskriptif dilakukan dengan menyajikan data dalam bentuk tabel, grafik, atau diagram. Dalam penelitian ini, gambaran kemiskinan anak disajikan dalam bentuk diagram lingkaran. Analisis inferensia digunakan untuk mengetahui pengaruh variabel prediktor terhadap kemiskinan anak. Analisis inferensia yang digunakan dalam penelitian ini adalah regresi logistik biner multilevel dengan random intercept karena mengasumsikan kesamaan pengaruh variabel prediktor terhadap kemiskinan anak. Model regresi logistik biner multilevel dengan random intercept adalah sebagai berikut:

Model pada level 1

$$
\ln \left[\frac{\pi_{i j k}}{1-\pi_{i j k}}\right]=\beta_{0 j k}+\sum_{p=1}^{P} \beta_{p i} X_{p i}+e_{i}
$$

Model pada level 2

$$
\beta_{0 j k}=\beta_{00 k}+\sum_{q=1}^{Q} \beta_{0 q} X_{q j}+e_{j}
$$

Model pada level 3

$$
\beta_{00 k}=\beta_{000}+\sum_{r=1}^{R} \beta_{0 r} X_{r k}+e_{k}
$$

Sehingga model regresi logistik biner multilevel dengan 3 level adalah sebagai berikut:

$$
Y_{i j k}=\ln \left[\frac{\pi_{i j k}}{1-\pi_{i j k}}\right]=\beta_{000}+\sum_{r=1}^{R} \beta_{0 r} X_{r k}+\sum_{q=1}^{Q} \beta_{0 q} X_{q j}+\sum_{p=1}^{P} \beta_{p i} X_{p i}+e_{i}+e_{j}+e_{k}
$$

Dimana:

$\begin{array}{ll}\mathrm{i} & =1,2, \ldots, \mathrm{I} \\ \mathrm{j} & =1,2, \ldots, \mathrm{J} \\ \mathrm{k} & =1,2, \ldots, \mathrm{K} \\ \mathrm{p} & =1,2, \ldots, \mathrm{P} \\ \mathrm{q} & =1,2, \ldots, \mathrm{Q} \\ \mathrm{r} & =1,2, \ldots, \mathrm{R}\end{array}$

Yijk : variabel respon unit ke-i level 1 dalam unit ke-j level 2 dalam unit ke-k level 3

$X_{\mathrm{pi}} \quad$ : variabel prediktor ke-p pada unit ke-i level 1

$\mathrm{X}_{\mathrm{qj}} \quad$ : variabel prediktor ke-q pada unit ke-j level 2

$X_{\mathrm{rk}} \quad$ : variabel prediktor ke-r pada unit ke-k level 3

$\beta_{0 \mathrm{jk}} \quad$ : random intercept unit ke-j level 2

$\beta_{00 \mathrm{k}} \quad$ : random intercept unit ke-k level 3

$\beta_{000}$ : fixed intercept

$\beta_{\mathrm{pi}} \quad$ : efek tetap untuk variabel prediktor ke-p level 1

$\beta_{0 q} \quad$ : efek tetap untuk variabel prediktor ke-q level 2

Bor : efek tetap untuk variabel prediktor ke-r level 3

$\mathrm{e}_{\mathrm{i}} \quad$ : residual level 1

$\mathrm{e}_{\mathrm{j}} \quad$ : residual level 2

$\mathrm{e}_{\mathrm{k}} \quad$ : residual level 3

Kemiskinan anak ditentukan menggunakan metode MODA yang dimodifikasi karena keterbatasan data dan penyesuaian dengan kondisi di Kepulauan Maluku dan Pulau Papua. Pengukuran kemiskinan anak dalam penelitian ini menggunakan 5 dimensi yang terdiri dari 9 indikator (Tabel 1). Seorang anak dianggap terdeprivasi pada suatu dimensi apabila tidak

\begin{tabular}{|c|c|c|c|c|}
\hline No & Dimensi & Indikator & Definisi Terdeprivasi & Sumber \\
\hline 1 & $\begin{array}{l}\text { Nutrisi dan } \\
\text { Makanan }\end{array}$ & $\begin{array}{l}\text { Konsumsi } \\
\text { kalori }\end{array}$ & $\begin{array}{l}\text { Anak umur } 0 \text { sampai } 4 \text { tahun } \\
\text { dengan konsumsi kalori kurang } \\
\text { dari AKG yang dianjurkan } \\
\text { Tabel } 1 \text {. AKG menurut umur }\end{array}$ & $\begin{array}{ll} & \text { Kerangka konsep MODA Indonesia } \\
\text { - } & \text { Peraturan Menteri Kesehatan RI } \\
\text { Nomor } 28 \text { Tahun } 2019 \text { tentang } \\
\text { Angka Kecukupan Gizi yang }\end{array}$ \\
\hline
\end{tabular}
terpenuhi hak-hak dasarnya minimal pada satu indikator. Kemudian, seorang anak dikatakan mengalami kemiskinan multidimensi apabila terdeprivasi pada minimal dua dimensi.

Tabel 34. Dimensi, indikator, definisi terdeprivasi, dan sumber MODA modifikasi 


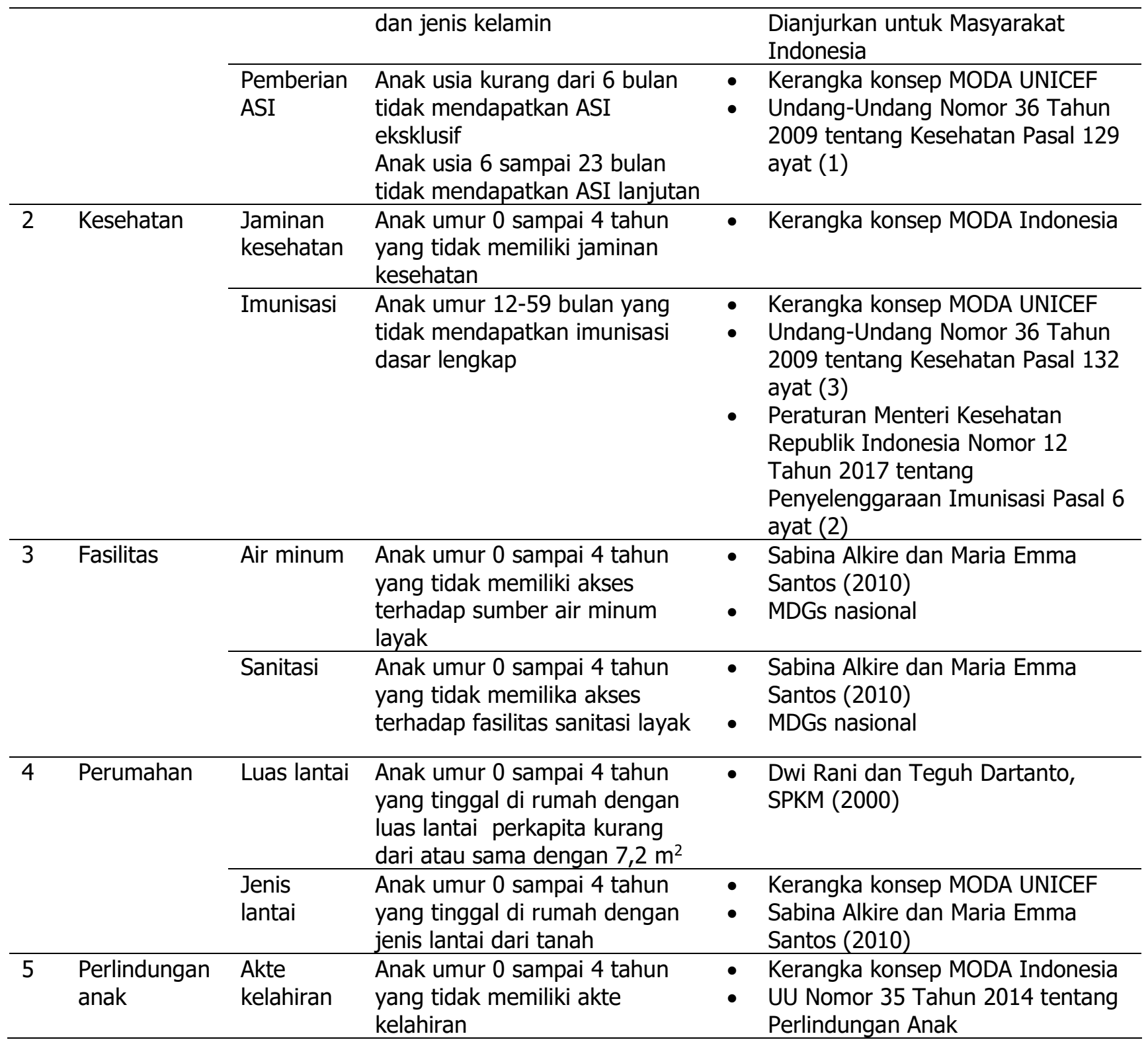

\section{HASIL DAN PEMBAHASAN}

Hasil analisis menunjukkan bahwa sebesar 87,8 persen balita di Kepulauan Maluku dan Pulau Papua mengalami kemiskinan. Dimensi utama penyebab kemiskinan balita adalah dimensi kesehatan, fasilitas, dan perumahan. Hampir 40 persen balita terdeprivasi pada dimensi kesehatan, fasilitas, dan perumahan secara bersamaan.

Analisis data menggunakan model regresi logistik biner multilevel diawali dengan membuat model tanpa variabel prediktor. Dalam penelitian ini, model tanpa variabel prediktor terdiri dari 2 model. Model 1 merupakan model 2 level dengan individu sebagai level 1 dan rumah tangga sebagai level 2. Sedangkan, Model 2 merupakan model 3 level dengan individu sebagai level 1, rumah tangga sebagai level 2, dan wilayah kabupaten/kota sebagai level 3. Nilai deviance Model 2 lebih kecil dari pada nilai deviance Model 1 (Tabel 2). Sehingga, model regresi logistik biner multilevel tanpa variabel prediktor terbaik adalah Model 2.

Tabel 2. Deviance model regresi logistik biner multilevel tanpa variabel prediktor

\begin{tabular}{|c|c|}
\hline Model & Deviance \\
\hline Model 1 & $7.965,4$ \\
\hline Model 2 & $7.262,9$ \\
\hline
\end{tabular}

Sumber: Susenas Maret 2019 (diolah) 
Uji signifikansi random effect diperlukan untuk mengetahui bahwa efek yang disebabkan variasi antar kelompok (level dua dan level tiga) signifikan di dalam model. $\mathrm{H}_{0}$ dari uji signifikansi random effect adalah random effect tidak signifikan. Penelitian ini menggunakan tingkat signifikansi 5 persen. Sehingga, $\mathrm{H}_{0}$ ditolak apabila $p$-value $<5$ persen. Nilai $p$-value dari statistik uji signifikansi random effect sebesar 0,000. Sehingga, dengan tingkat kepercayaan 95 persen dapat disimpulkan bahwa random effect signifikan. Dengan kata lain, terdapat keragaman variabel respon antar kelompok karena efek random signifikan.

Besarnya keragaman variabel respon yang disebabkan oleh perbedaan karakteristik antar kelompok dapat diketahui dengan menghitung nilai Intraclass Correlation Coefficiet (ICC). Nilai ICC level rumah tangga sebesar 23,9 persen dan nilai ICC level kabupaten/kota sebesar 32,0 persen. Hal tersebut dapat diartikan 23,9 persen keragaman status kemiskinan balita disebabkan oleh perbedaan karakteristik antar rumah tangga dan 32 persen keragaman status kemiskinan balita disebabkan oleh perbedaan karakteristik antar wilayah kabupaten/kota.

Tabel 3. Variance dan Intraclass Correlation Coefficient

\begin{tabular}{lcc}
\hline Model & Variance & ICC \\
\hline$\sigma_{\mathrm{e}}^{2}$ & $\Pi^{2} / 3=3,29$ & - \\
$\sigma^{2}$ uo & 1,785 & 0,239 \\
$\sigma^{2}$ vo & 2,393 & 0,320 \\
\hline
\end{tabular}

Sumber: Susenas Maret 2019 (diolah)

Langkah selanjutnya adalah memasukkan variabel prediktor dalam model regresi logistik biner multilevel dengan random intercept. Dalam penelitian ini, model regresi logistik biner multilevel dengan random intercept terdiri dari 3 model yaitu Model 3, Model 4, dan Model 5 . Model 3 merupakan Model 2 beserta variabel prediktor level 1 . Model 4 merupakan Model 2 beserta variabel prediktor level 1 dan level 2 . Model 5 merupakan Model 2 beserta variabel prediktor level 1 , level 2 dan level 3. Nilai deviance Model 5 lebih kecil dari pada nilai deviance Model 3 dan Model 4 (Tabel 4). Dengan demikian, model regresi logistik biner multilevel dengan random intercept terbaik adalah Model 5.

Tabel 4. Deviance model regresi logistik biner multilevel beserta variabel prediktor

\begin{tabular}{|c|c|}
\hline Model & Deviance \\
\hline Model 3 & $7.215,9$ \\
\hline Model 4 & $6.467,7$ \\
\hline Model 5 & $6.436,3$ \\
\hline
\end{tabular}

Sumber: Susenas Maret 2019 (diolah)

Berdasarkan hasil analisis regresi logistik biner multilevel (Tabel 5), karakteristik individu yang signifikan memengaruhi status kemiskinan balita adalah umur balita. Kemudian, karakteristik rumah tangga yang signifikan memengaruhi status kemiskinan balita adalah pendidikan kepala rumah tangga, pendidikan ibu, status bekerja ibu, umur kepala rumah tangga, jumlah anggota rumah tangga, kemiskinan rumah tangga, dan tipe daerah. Sedangkan, karakteristik wilayah yang signifikan memengaruhi status kemiskinan balita adalah IPM. Kemiskinan balita di Kepulauan Maluku dan Pulau Papua cenderung terjadi pada balita umur 0 sampai 1 tahun. Kemiskinan balita di Kepulauan Maluku dan Pulau Papua juga cenderung terjadi pada anak yang tinggal di rumah tangga dengan kepala rumah tangga maksimal tamat SD, kepala rumah tangga berumur maksimal 25 tahun, ibu maksimal tamat SD, ibu tidak bekerja, rumah tangga miskin, rumah tangga dengan jumlah anggota rumah tangga lebih dari 4, dan rumah tangga di daerah pedesaan. Selain itu, kemiskinan balita cenderung terjadi pada balita yang tinggal di wilayah kabupaten/kota dengan IPM rendah. Penelitian oleh Adetola dan Olufemi (2012) menunjukkan hasil yang sama yaitu umur anak, pendidikan orangtua, umur kepala rumah tangga, jumlah anggota rumah tangga, dan fasilitas kesehatan menentukan kemiskinan anak. Hasil penelitian tersebut juga sejalan dengan penelitian Pusponegoro (2013) dan Bachtiar (2016) yang menyatakan bahwa pendidikan kepala rumah tangga signifikan memengaruhi kemiskinan balita. Selain itu, hasil penelitian Pusponegoro (2013) juga menunjukkan bahwa pendidikan ibu dan wilayah tempat tinggal signifikan 
memengaruhi kemiskinan balita. Kemudian, penelitian Meriyanti (2015) menyatakan bahwa IPM berhubungan dengan pengentasan kemiskinan serta berpengaruh positif dan signifikan terhadap kemiskinan.

Tabel 5. Hasil analisis regresi logistik biner multilevel

\begin{tabular}{lccccc}
\hline \multicolumn{7}{c}{ Variabel } & Penduga & S.E & Wald & Sig. & Odds Ratio \\
\hline Intercept & 2,373 & 0,572 & 4,146 & $0,000^{*}$ & - \\
\hline \multicolumn{7}{c}{ Karakteristik individu } \\
\hline UmurBalita(1) & 0,513 & 0,081 & 6,324 & $0,000^{*}$ & 1,670 \\
UmurBalita(2) & 0,314 & 0,100 & 3,127 & $0,000^{*}$ & 1,369 \\
JenisKelaminBalita(1) & $-0,049$ & 0,073 & $-0,669$ & 0,504 & 0,952 \\
\hline \multicolumn{6}{c}{ Karakteristik rumah tangga } \\
\hline PendidikanKRT(1) & 0,731 & 0,103 & 7,113 & $0,000^{*}$ & 2,077 \\
PendidikanIbu(1) & 0,624 & 0,094 & 6,627 & $0,000^{*}$ & 1,866 \\
StatusBekerjaKRT(1) & $-0,249$ & 0,147 & $-1,691$ & 0,091 & 0,779 \\
StatusBekerjaIbu(1) & 0,169 & 0,079 & 2,159 & $0,031^{*}$ & 1,184 \\
UmurKRT(1) & 0,849 & 0,241 & 3,525 & $0,000^{*}$ & 2,337 \\
JumlahART(1) & 0,369 & 0,080 & 4,556 & $0,000^{*}$ & 1,446 \\
KemiskinanRumahTangga(1) & 1,998 & 0,177 & 11,259 & $0,000^{*}$ & 7,374 \\
TipeDaerah(1) & 0,426 & 0,099 & 4,293 & $0,000^{*}$ & 1,531 \\
\hline \multicolumn{7}{c}{ Karakteristik wilayah } \\
\hline IPM(1) & 0,143 & 0,643 & 0,222 & 0,844 & 1,154 \\
IPM(2) & 0,361 & 0,567 & 0,636 & 0,525 & 1,435 \\
IPM(3) & 1,777 & 0,598 & 2,972 & $0,003^{*}$ & 5,912 \\
\hline Sumbi
\end{tabular}

Sumber: Susenas Maret 2019 (diolah)

*signifikan pada taraf uji 5 persen

Reference: UmurBalita=37 sampai 59 bulan, JenisKelaminBalita = laki-laki, PendidikaKRT= $\geq S M P /$ sederajat, PendidikanIbu $=\geq S M P /$ sederajat, StatusBekerjaKRT = bekerja, StatusBekerjaIbu $=$ bekerja, UmurKRT $=>25$ tahun, JumlahART= maksimal 4, TipeDaerah= perkotaan, StatusKemiskinan= tidak miskin, IPM= sangat tinggi.

\section{KESIMPULAN}

Berdasarkan hasil penelitian, dapat disimpulkan bahwa 9 dari 10 balita di Kepulauan Maluku dan Pulau Papua mengalami kemiskinan. Karakteristik individu, rumah tangga, dan wilayah kabupaten/kota signifikan memengaruhi status kemiskinan balita di Kepulauan Maluku dan Pulau Papua. Status kemiskinan balita di Kepulauan Maluku dan Pulau Papua dipengaruhi oleh karakteristik individu (umur balita), rumah tangga (pendidikan dan umur kepala rumah tangga, pendidikan dan status bekerja ibu, status kemiskinan dan jumlah anggota rumah tangga, serta tipe daerah), dan wilayah (IPM).

\section{UCAPAN TERIMAKASIH}

Terimasih kepada Badan Pusat Statistik yang telah memberikan data penelitian serta pihakpihak yang telah membantu penulis dalam melakukan penelitian.

\section{DAFTAR PUSTAKA}

Adetola, A., \& Olufemi, P. (12 Oktober 2012). Determinants of Child Poverty in Rural Nigeria: A Multidimensional Approach. Global Journal of Human-Social Science Research, 12(12), 39-53. Diakses pada 23 Oktober 2019 https://socialscienceresearch.org/index.php/GJHSS/article/view/403/356.

Bachtiar, N., Rasbi, M.J., \& Fahmi, R. (1 Juni 2016). Analisis Kemiskinan Anak Balita pada Rumah Tangga di Provinsi Sumatera Barat. Jurnal Kependudukan Indonesia, 11 (1), 29-38.

BPS. (2017). Analisis Kemiskinan Anak dan Deprivasi Hak-Hak Dasar Anak di Indonesia. Jakarta: BPS. 
Bastos, A., \& Machado, C. (2009). Child poverty: a multidimensional measurement. International Journal of Social Economics, 36(3), 237-251. Diakses pada 21 Oktober 2019 melalui http://dx.doi.org/10.1108/03068290910932738.

Bronfenbrenner, Uri. (1979). The Ecology of Human Development: Experiments by Nature and Design. United States: President and Fellows of Harvard College.

de Neubourg, et al. (2012). Child Deprivation, Multidimensional Poverty and Monetary Poverty in Europe. Innocenti Working Paper No. 2012-02, UNICEF Innocenti Research Centre, Florence.

Duncan, G.J. \& Magnuson, K. (2013). The Long Reach of Early Childhood Poverty. USA.

Fajth, Gaspar. (n.d). Child poverty/outcome determinants \& feedback loops in the Global Study, Slides. UNICEF DPP.

Feeney, \& Boyden. (2003). Shaping a Response to Poverty: A Conceptual Overview and Implications for Responding to Children Living in Poverty. Christian Children's Fund Children and Poverty Series.

Harianto, S. (2018). Relasi Orang Miskin dan Kebijakan Penanggulangan Kemiskinan. Makalah dipresentasikan pada Seminar Nasional Riset Inovatif (SENARI) III, Bali, Indonesia.

Hox, J.J. (2018). Multilevel Technique and Applications Quantitative Methodology Series ( $3^{\text {rd }}$ ed). New York: Routledge.

Karisma, B. (2017). Assesing the Impact of Cash Transfer on Social Capital in Indonesia. Diakses pada 11 Januari 2020 melalui www.researchgate.net/publication/315797463

Meriyanti, N. K. (2015). Pengaruh Program Indeks Pembangunan Manusia (IPM) terhadap Pengentasan Kemiskinan di Kecamatan Buleleng Tahun 2011-2014. Jurnal Jurusan Pendidikan Ekonomi Undiksha, $5(1)$.

Prasetyo, H. (2010). Determinan Deprivation dan Kemiskinan Anak di Indonesia [Tesis]. Depok: Program Pasca Sarjana Kependudukan dan Sumber Daya Manusia Universitas Indonesia.

Pusponegoro, N. H. (2013). Kemiskinan Anak Usia Kurang dari Lima Tahun pada Rumah Tangga dengan Rata-Rata Pengeluaran yang Terletak pada Kuantil Pertama Tahun 2008-2010 di Indonesia. Makalah dipresentasikan pada Child Poverty and Social Protection Conference, Indonesia.

Ramadhani, A.W., \& Munandar, A.I. (Agustus 2019). Determinan Kemiskinan Anak di Provinsi DKI Jakarta: Susenas 2017. Jurnal Ekonomi Kuantitatif Terapan, 12(2), 111-123.

Sutikno, Soedjono, E.S., Rumiati, A.T., \& Trisunarmo, L. (2010). Pemilihan Program Pengentasan Kemiskinan Melalui Pengembangan Model Pemberdayaan Masyarakat dengan Pendekatan Sistem. Jurnal Ekonomi Pembangunan, 11(1), 135-147.

UNICEF. (2005). THE STATE OF THE WORLD'S CHILDREN 2005: Childhood under Threat. New York: UNICEF. 